\title{
Evaluation of Bio- and Mineral Phosphorus Fertilizers Accompanied with Foliar Application of Micronutrients on Quantity and Quality of Soybean (Glycin max L.) Yield
}

\author{
Manal A. Attia, Dalia A. Sayed and Lamyaa A. Abdel-Rahman \\ Soils, Water and Environment Research Institute, Agricultural \\ Research Center, Giza, Egypt.
}

\begin{abstract}
A
FIELD experiment was carried out to investigate the effect of different levels of phosphorus fertilizer application $\mathrm{P}_{0}$ (without $\mathrm{P}$ fertilizer), $\mathrm{P}_{1}\left(15 \mathrm{~kg} \mathrm{P}_{2} \mathrm{O}_{5} /\right.$ fed $), \mathrm{P}_{2}\left(22.5 \mathrm{~kg} \mathrm{P}_{2} \mathrm{O}_{5} / \mathrm{fed}\right)$ and the recommended dose $\mathrm{P}_{3}\left(30 \mathrm{~kg} \mathrm{P}_{2} \mathrm{O}_{5} / \mathrm{fed}\right)$, either alone or in combination with phosphorus biofertilizer (phosphorus solubilizing bacteria Bacillus megatherium $)$ and foliar spray of micronutrients $(\mathrm{Fe}+\mathrm{Mn}+\mathrm{Zn}$ at mixture rate $1: 1: 1)$ on yield, yield components and seed quality of soybean. The results showed that the yield and its components were significantly increased with the levels of mineral P-fertilizers, biological P-fertilizers and foliar spray of micronutrients alone or in combination. Also, the results disclosed that the highest values of yield components were obtained with combination of $\mathrm{P}$ rate of $22.5 \mathrm{~kg} \mathrm{P}_{2} \mathrm{O}_{5} /$ fed with inoculation of $\mathrm{P}-$ biofertilizer and foliar spray of micronutrients. Application of phosphorus at the rate of $22.5 \mathrm{~kg} \mathrm{P}_{2} \mathrm{O}_{5} /$ fed in combination with phosphorus dissolving bacteria significantly increased the uptake of macro-, micro-nutrients, protein and oil contents. Moreover, the combined application of mineral phosphorus and foliar micronutrients application had positive effect on $\mathrm{N}$, $\mathrm{K}$, Mn, as well as protein and oil content. The interaction between phosphorus level at $22.5 \mathrm{~kg} \mathrm{P}_{2} \mathrm{O}_{5} / \mathrm{fed}$, phosphorus biofertilizer and foliar micronutrients had significant influence on uptake of $\mathrm{K}, \mathrm{Fe}$ and $\mathrm{Mn}$ in seeds of soybean plants. Therefore, it could be concluded that, biofertilizers could replace a portion of the chemical fertilizers in soybean production reducing environment problems linked to the mineral fertilizers.
\end{abstract}

Keyword: Biofertilizer, Phosphorus, Micronutrients, Soybean.

Soybean (Glycine max L.) is one of the most important summer leguminous crops, extensively successful in many provinces in Egypt and worldwide. It consists of around $20 \%$ oil and $40 \%$ protein. Therefore, it is an excellent source of food for human and animal consumption (Abdelhamid and El-Matwally, 2008). Soybean oil is one of the common vegetable oils containing a significant amount of unsaturated fatty acids including linolenic acid (omega-3 fatty acid), linoleic acid (omega-6 fatty acid) and oleic acid (omega-9 fatty acid) (Yaklich et al., 2002). Its dietary composition is reported to be the best in the legume family containing vitamins good for diabetics (Agwu et al., 2009).

The use of fertilizer is considered to be one of the most important factors in increasing crop yield. Phosphorous has been shown to be an essential element and its application has been shown to be important for growth, development and yield 
of soybean (Kakar et al., 2002). Phosphorus is an important plant nutrient involved in several energy transformation and biochemical reactions including biological nitrogen fixation. Phosphorus fertilizers have low efficiency of utilization due to chemical fixation in soil (MeviSchutz et al., 2003). Phosphorus deficiency can cause a limit nodulation in legumes and $\mathrm{P}$ fertilizer application can also overcome this deficiency (Carsky et al., 2001). The use of phosphate solubilizing bacteria is able to change insoluble phosphorus in soil into the absorbed soluble form (Turan et al., 2006). El-Gizawy and Mehasen (2009) showed that application of mineral phosphorus fertilizer with phosphate- solubilizing bacteria had a significant effect on bean seed yield and its components, nitrogen, phosphorus and zinc content in seeds. Seeds inoculated with biofertilizers in combination with foliar application of micronutrients gave higher values of all estimated parameters of pea bean than plants fertilized with chemical fertilizers in the presence or absence of foliar application (Zaghloul et al., 2015). In all cases, fertilizers are major factors in maintaining soil fertility, but using too much of them, greatly reduce the amount of soil microorganisms. Environmental problems caused by irregular application of chemical fertilizers have harmful effects on biological cycles and destroyed farming stability systems; these factors altogether encourage the application of biofertilizers (Kannayan, 2002). Integration of chemical and biofertilizers is one of the ways to increase production in sustainable agriculture (Ali et al., 2008). From otherwise, one biological way to increase the productivity in the agricultural sector is the effective use of beneficial microorganisms that have more ability to enhance plant growth and yield.

Micronutrients application led to enhance plant productivity, leaf area and grain yield as result of increasing the enzymatic system of plants (Zayed et al., 2011). Micronutrients foliar application treatment showed a significant effect on the produced the highest values of plant height at harvest, number of branches per plant, number of pods per plant, 100 seed weight, seed yield per plant, seed yield $\left(\mathrm{kg} \mathrm{ha}^{-1}\right)$, oil content, oil yield, protein content and its yield of soybean compared with control treatment (El-Haggan, 2014).

Therefore, the objective of this study was to evaluate the role of phosphate solubilizing bacteria in soybean production as well as to study the possibility of decreasing rate of mineral P-fertilizer in presence of these bacteria as a growth motive in increasing the solubility and absorption of phosphate fertilizers.

\section{Materials and Methods}

A field experiment was carried out during two summer seasons (2013 and 2014) in Gemmeiza Agri. Res. Station, Gharbia Governorate located at lat. 30.47, long 31.00 and $14.80 \mathrm{~m}$ above the sea level to evaluate the effect of different levels of mineral P-fertilizer combined with or without phosphorus solubilizing bacteria (Bacillus megatherium) and foliar spray of micronutrients on yield and its attributes, nutrients uptake and quality of soybean. Soil samples were taken for physical properties according to KLute (1986). Soil samples were subjected to the chemical properties including determination of the available $\mathrm{N}, \mathrm{P}$ and $\mathrm{K}$ as 
outlined according to Page et al. (1982). The physical and chemical properties of the experiment soil were presented in Table 1.

TABLE 1. Physical and chemical properties of the soil used.

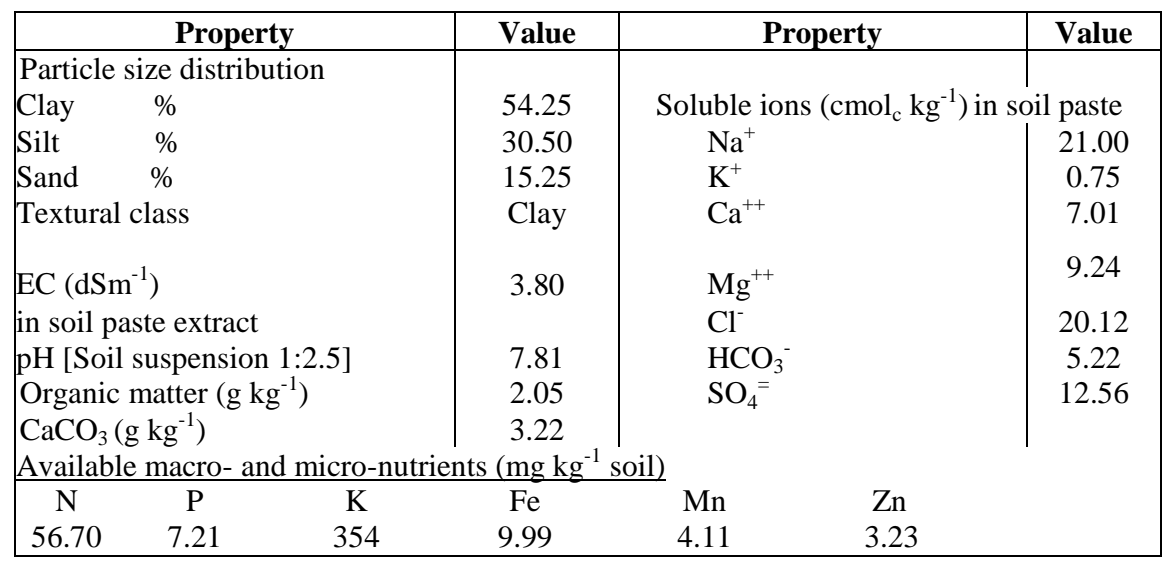

Experiment was conducted in split split plots design in complete randomized blocks with three replicates. The main plots included non-inoculated plant $\left(\mathrm{B}_{0}\right)$ and inoculated plant $\left(\mathrm{B}_{1}\right)$, sub-plot was considered four levels of mineral $\mathrm{P}$ fertilizers $\left(\mathrm{P}_{0}, \mathrm{P}_{1}, \mathrm{P}_{2}\right.$ and $\left.\mathrm{P}_{3}\right)$, while sub-sub plot represented in presence $\left(\mathrm{F}_{1}\right)$ and absence $\left(\mathrm{F}_{0}\right)$ of foliar application of micronutrients. Concerning Bio-fertilizer, phosphorin (Bacillus megaterium var. phospaticium), was supplied by Biofertilizers Production Unit, Soil Microbiology Dept. Soils, Water and Environment Res. Inst., Agric. Res. Center. Giza, Egypt. Inoculation with phosphorin as a bio-fertilizer was performed through mixing seeds with appropriate amount of this inculator $(200 \mathrm{~g} / \mathrm{fed})$.

Soybean (cv. Giza 111) obtained from Crops Institute, Agriculture Research Center, Giza, Egypt. Seeds were inoculated with biofertilizer using Arabic gum as an adhesive material just prior to sowing. The micronutrients treatments were a combination in the form of EDTA compound of Fe-EDTA (12\%), Zn-EDTA $(14 \%)$ and Mn-EDTA (12\%) with a ratio of 1:1:1 (using $0.2 \mathrm{~g}$ of each element/L). Foliar spray solution from the mixture of the chelated compounds was applied at a rate of $200 \mathrm{~L} /$ fed in two times, the first was 40 days after sowing and the second was a month later.

The four levels of mineral phosphorus namely $\mathrm{P}_{0}$ (without $\mathrm{P}$ fertilizer), $\mathrm{P}_{1}$ (15 $\mathrm{kg} \mathrm{P}_{2} \mathrm{O}_{5} /$ fed $), \mathrm{P}_{2}\left(22.5 \mathrm{~kg} \mathrm{P}_{2} \mathrm{O}_{5} /\right.$ fed $)$ and the recommended dose $\mathrm{P}_{3}(30 \mathrm{~kg}$ $\left.\mathrm{P}_{2} \mathrm{O}_{5} / \mathrm{fed}\right)$ were added before planting in the form of calcium super phosphate $\left(15.5 \% \mathrm{P}_{2} \mathrm{O}_{5}\right)$. The recommended doses of $\mathrm{N}(50 \mathrm{~kg} / \mathrm{fed})$ as urea $(46.5 \% \mathrm{~N})$ and $\mathrm{K}$ $(24 \mathrm{~kg} / \mathrm{fed})$ as potassium sulphate $\left(48 \% \mathrm{~K}_{2} \mathrm{O}\right)$ were applied to all treatments at the proper time. Sowing of soybean seeds was carried out on the $20^{\text {th }}$ and $25^{\text {th }}$ of May in the first and second seasons, respectively. At harvest, seed yield and its components were estimated. Seed oil percent was age estimated according to 
AOAC (1990). Crude protein content was also calculated by multiplying $\mathrm{N} \%$ by 6.25 as described by Hymowitz et al. (1972). Yield data were statistically analyzed according to Snedecor and Cochran (1990).

\section{Results and Discussion}

\section{Seed yield and its attributes}

Data revealed that increasing levels of $\mathrm{P}$ fertilizers were significant increases over that of $\mathrm{P}_{0}$ (control) in 100 seed weight, pod, straw and seed yields (Table 2). Also, increasing the rate of P-fertilizers up to $75 \%\left(\mathrm{P}_{2}\right)$ from $\left(30 \mathrm{~kg} \mathrm{P}_{2} \mathrm{O}_{5}\right)$ caused significant increases in 100 seed weight and pod yield, and up to $100 \%\left(\mathrm{P}_{3}\right)$ in case of seed yield. These data were confirmed with results considering that leguminous crops require more phosphorus than other crops to attain optimum growth and productivity (Gitari and Murith, 2003). However, the results are in agreement with that obtained by Tomar et al. (2004) and Qasim et al. (2009) who stated that increased levels of $\mathrm{P}$ had a positive effect on 100-seed weight, number of pods and seed yield of soybean. Similar results were obtained also by Zarei $e t$ al. (2012). In addition, significant increases were achieved in faba bean yield and its attributes by increasing phosphorus fertilization rate up to $46 \mathrm{~kg} \mathrm{P}_{2} \mathrm{O}_{5}$ / fed (ElGizawy and Mehasen, 2009). The increase in seed yield might be associated with high number of pods/plant, 100-seed weight and seed yield. The results are in accordance with those obtained by Ahmed and El-Abagy (2007).

Application of bio-fertilizer or micronutrient spraying individually caused significant superiority in the mentioned estimations to that without any of them. Regarding the effect of micronutrients spray, the results showed that, treating seeds with micronutrients as foliar application significantly improves the yield and its components rather than without using foliar application. Such increase indicates the efficiency of applying micronutrients by foliar method in correcting micronutrients deficiency that improve nutrients balance, use of NPK fertilizers and yield in turn. Thus, bio-fertilizer and/or micronutrients spraying raised the applied $\mathrm{P}$ rate use efficiency. It can be noted that, plants treated with $\mathrm{P}$ biofertilizer and foliar application of micronutrients were more effective than plants without $\mathrm{P}$ biofertilizer and foliar application of micronutrients recording $55 \%, 33 \%, 24 \%$ and $29 \%$ for weight of 100 -seeds, pods, straw and seed yield, respectively. In this regard, Amara (1998) found that spraying with micronutrients resulted in a large increase in total microbial counts in rhizosphere and increased nodule numbers and weights on bean yield. Imtiaz et al. (2003) stated that lack of just one micronutrient can greatly reduce plant yield. Furthermore, data in Table 2 reveal that treating seeds with P- biofertilizer significantly increased the yield and its components compared with noninoculated seeds. Bio-fertilizer results are in accordance with those obtained by Mekail et al. (2005) and Yilmaz (2008). Also, IIbas and Sahn (2005) in their work on soybean showed that inoculation with phosphorus has significant effect on 1000 -seed weight. 
TABLE 2. The effect of all treatments used on yield components and yields.

\begin{tabular}{|c|c|c|c|c|c|c|c|c|c|c|c|}
\hline \multirow[t]{2}{*}{$\begin{array}{c}\text { Grow th } \\
\text { characters }\end{array}$} & \multirow[t]{2}{*}{$\underset{\text { level }}{\mathbf{P}}$} & \multicolumn{2}{|c|}{$\begin{array}{l}\text { Without Bio-P- } \\
\text { Fert }\left(B_{0}\right)\end{array}$} & \multicolumn{2}{|c|}{$\begin{array}{c}\text { With Bio-P- } \\
\text { Fert }\left(B_{1}\right)\end{array}$} & \multirow{2}{*}{$\underset{\text { Mean }}{P}$} & \multicolumn{2}{|c|}{ Mean of PF } & \multicolumn{2}{|c|}{ Mean of P.B } & \multirow{2}{*}{ L.S.D at $5 \%$} \\
\hline & & $F_{0}$ & $F_{1}$ & $F_{0}$ & $F_{1}$ & & $F_{0}$ & $\mathbf{F}_{1}$ & $\mathbf{B}_{\mathbf{0}}$ & $\mathbf{B}_{1}$ & \\
\hline \multirow{5}{*}{ 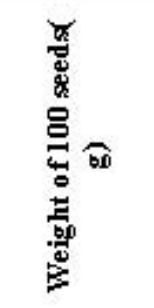 } & $P_{0}$ & $9.32^{k}$ & $11.38^{j}$ & $14.07^{\mathrm{h}}$ & $15.84^{\mathrm{g}}$ & $12.65^{c}$ & $11.69^{\mathrm{g}}$ & $13.61^{\mathrm{f}}$ & $10.35^{f}$ & $1492^{e}$ & \multirow{5}{*}{$\begin{array}{lc}\text { P } & 0.57 \\
\text { B } & 0.35 \\
\text { F } & 0.22 \\
\text { P. B } & 0.70 \\
\text { P.F } & 0.43 \\
\text { B.F } & 0.31 \\
\text { P.B.F } & 0.60\end{array}$} \\
\hline & $\mathbf{P}_{\mathbf{1}}$ & $12.82^{i}$ & $15.84^{g}$ & $17.08^{\mathrm{f}}$ & $19.8^{\mathrm{kx}}$ & $1637^{b}$ & $1495^{e}$ & $17.80^{d}$ & $1431^{e}$ & $18.44^{c}$ & \\
\hline & $\mathbf{P}_{2}$ & $16.75^{f}$ & $1759^{\mathrm{e}}$ & $20.03^{b}$ & $23.60^{2}$ & $1936^{2}$ & $1839^{x}$ & $19.54^{b}$ & $17.17^{d}$ & $21.82^{a}$ & \\
\hline & $\mathbf{P}_{3}$ & $18.19^{d}$ & $18.74^{\mathrm{d}}$ & $20.18^{b}$ & $20.35^{b}$ & $19.49^{\mathrm{a}}$ & $19.19^{b}$ & $20.60^{2}$ & $18.46^{\circ}$ & $20.27^{b}$ & \\
\hline & Mean & 14.27 & 15.84 & 17.84 & 19.90 & 17.00 & 16.41 & 17.89 & 15.06 & 18.86 & \\
\hline \multirow{5}{*}{ 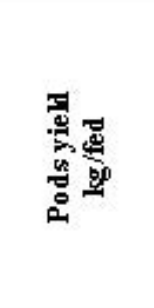 } & $P_{0}$ & $1742^{h}$ & $2097^{\mathrm{g}}$ & $2406^{f}$ & $2591^{\mathrm{f}}$ & $2209^{d}$ & $2074^{\mathrm{g}}$ & $2344^{f}$ & $1919^{f}$ & $2498.8^{e}$ & \multirow{5}{*}{$\begin{array}{l}\text { P } 92.93 \\
\text { B } 79.33 \\
\text { F } 10795 \\
\text { P.B } 158.67 \\
\text { P.F } 215.89 \\
\text { B.F } 158.67 \\
\text { P.B. F } 30532\end{array}$} \\
\hline & $\mathbf{P}_{1}$ & $2573^{f}$ & $2700^{6}$ & $3073^{d}$ & $3224^{\mathrm{cd}}$ & $2892^{x}$ & $2823^{e-1}$ & $2962^{1}$ & $2636^{e}$ & $3148.82^{c}$ & \\
\hline & $\mathbf{P}_{2}$ & $2706^{d f}$ & $2993^{i k}$ & $3440^{c}$ & $5046^{a}$ & $3366^{b}$ & $3073^{x d}$ & $3528^{b}$ & $2850^{d}$ & $424333^{2}$ & \\
\hline & $\mathbf{P}_{3}$ & $3015^{d}$ & $3195^{d 1}$ & $3393^{c}$ & $3862^{b}$ & $3546^{2}$ & $3204^{c}$ & $4020^{2}$ & $3105^{c}$ & $3627.83^{b}$ & \\
\hline & Mean & 2509 & 2746 & 3078 & 3681 & 3004 & 2794 & 3214 & 2630 & 33800 & \\
\hline \multirow{5}{*}{ 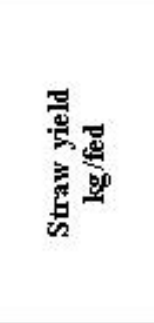 } & $P_{0}$ & $1306^{k}$ & $1686^{\mathrm{pk}}$ & $2120^{\mathrm{i}}$ & $2133^{\mathrm{hi}}$ & $1811^{d}$ & $1713^{e}$ & $1910^{e}$ & $1496^{f}$ & $2126.67^{e}$ & \multirow{5}{*}{$\begin{array}{l}\text { P } 199.40 \\
\text { B } 160.42 \\
\text { F } 138.76 \\
\text { P.B } 320.84 \\
\text { P.F } 27752 \\
\text { B. F } 196.24 \\
\text { P.B. F } 392.48\end{array}$} \\
\hline & $\mathbf{P}_{1}$ & $2066^{\overline{3}}$ & $2573^{\mathrm{fg}}$ & $3780^{e}$ & $3960 d^{e}$ & 3095 & $2923^{d}$ & $3266^{c}$ & $2320^{e}$ & $3870.0^{x}$ & \\
\hline & $\mathbf{P}_{2}$ & ${ }_{i}^{2233 g^{n}}$ & $4173^{d-}$ & $4764^{b}$ & $5893^{2}$ & $3941^{b}$ & $3498^{c}$ & $4433^{b}$ & $3203^{d}$ & $5328.83^{2}$ & \\
\hline & $\mathbf{P}_{3}$ & $2360^{\mathrm{ght}}$ & $4180^{d 1}$ & $4540 b^{c}$ & $4686^{b}$ & $4266^{2}$ & $3450^{c}$ & $5033^{2}$ & $3270^{d}$ & $4613.33^{b}$ & \\
\hline & Mean & 1991 & 3153 & 3801 & 4168 & 3279 & 2896 & 3661 & 2573 & 39850 & \\
\hline \multirow{5}{*}{ 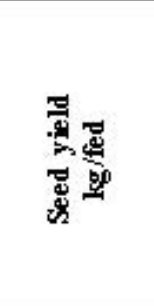 } & $P_{0}$ & $505^{1}$ & $535^{1 \mathrm{~d}}$ & $570^{k}$ & $757^{\mathrm{fgh}}$ & $592^{\mathrm{d}}$ & $537^{f}$ & $646^{e}$ & $520^{f}$ & $663.61^{e}$ & \multirow{5}{*}{$\begin{array}{ll}\text { P } & 15.16 \\
\text { B } & 19.98 \\
\text { F } & 12.49 \\
\text { P.B } & 39.95 \\
\text { P.F } & 24.98 \\
\text { B.F } & 39.95 \\
\text { P.B.F } & 35.43\end{array}$} \\
\hline & $\mathbf{P}_{1}$ & $633^{j}$ & $706^{i}$ & $766^{\mathrm{fgh}}$ & $1013^{x}$ & $779^{\circ}$ & $699^{d}$ & $860^{b}$ & $670^{e}$ & $889.83^{x}$ & \\
\hline & $\mathbf{P}_{2}$ & $740 \mathrm{~h}^{\mathrm{i}}$ & $749 \mathrm{~g}^{\mathrm{h}}$ & $949^{d}$ & $1214^{a}$ & $886^{h}$ & $844 b^{c}$ & $956^{2}$ & $744 d$ & $1081.83^{2}$ & \\
\hline & $\mathbf{P}_{3}$ & $787^{\mathrm{f}}$ & $779^{\mathrm{fg}}$ & $845^{e}$ & $1134^{b}$ & $913^{a}$ & $816^{6}$ & $981^{2}$ & $783^{1}$ & $98950^{b}$ & \\
\hline & Mean & 666 & 692 & 782 & 1029 & 793 & 724 & 861 & 680 & 906 & \\
\hline
\end{tabular}

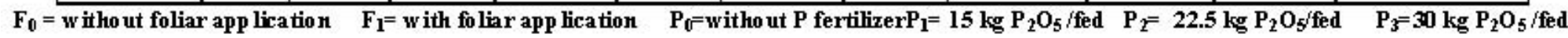


Many investigators obtained similar results of the interaction between the $\mathrm{P}$ rates of bio-fertilizer and spraying micronutrients including (1) due to mineral $\mathrm{P}$ application and P-bio-fertilization (Singh et al. 2008; Selvakumar et al. 2012 and Uddin et al. 2014), (2) due to mineral $\mathrm{P}$ application and micronutrients foliation (Kashturikrishna and Ahlawat, 1999) and (3) due to P bio-fertilization and micronutrients spraying (Amara, 1998). This might be due to combined stimulating effect of phosphorus dissolving bacteria and $\mathrm{P}$ fertilizer levels in supplying the growing plants with their phosphorus requirements.

Concerning the trible interaction between the treatments of $\mathrm{P}_{2} \mathrm{~B}_{1} \mathrm{~F}_{1}$ was significantly the best one. The relative increase for weight of 100 seeds, pods, straw and seed yield were $30 \%, 67 \%, 150 \%$ and 54\%, respectively, compared with $\mathrm{P}_{3}\left(30 \mathrm{~kg} \mathrm{P}_{2} \mathrm{O}_{5}\right)$ without bio-fertilizer or micronutrients spraying in the two studied seasons. This may be attributed to the plant growth promoting substances produced by the bio-fertilizer, in addition to the reasonable quantity of atmospheric nitrogen fixed by Azotobacter chrococcum. These reactions saved more available nutrients for enzymes required to build up the different organs compounds and consequently for better growing soybean plant. The general physiological status of the plants as indicated by the dry weight always exhibited positive response to use bio-fertilizer addition. These results are in accordance with Hamed (2003) in his work on faba bean and El- Gizawy and Mehasn (2009) who concluded that adding $40 \mathrm{~kg} \mathrm{P}_{2} \mathrm{O}_{5}$ mixed with phosphate dissolving bacteria (PDB) under spraying of $0.04 \% \mathrm{Zn}$ EDTA (14\% Zn) may be the recommended treatment for improving the productivity of faba bean crop. Thus, it could be recommended that using $\mathrm{P}_{2}$ (i.e., $75 \%$ from the recommended $\mathrm{P}$ application rate) in presence of $\mathrm{P}$ bio-fertilization and micronutrients spraying gave the best significant results for 100 seed weight, pod, straw and seed yields of soybean under the experiment condition as compared to applying higher inorganic $\mathrm{P}$ fertilizer levels, which exert a massive cost on the farmer (Dutta and Prohit, 2009).

\section{Nutrients uptake \\ Macronutrients}

As indicated by the effect of phosphorus levels, the data in Table 3 showed that not only the positive effect of $\mathrm{P}$ application on $\mathrm{P}$ uptake, as expected, but also its significant positive effect on $\mathrm{N}$ and $\mathrm{K}$ uptake. Also, raising the rate of $\mathrm{P}$ application up to $100 \%\left(\mathrm{P}_{3}\right)$ achieved the highest values for the aforementioned parameters. Therefore, the application of phosphorus has a dramatic effect on legumes when it applied to soils low in phosphorus. Phosphorus helps legumes plants in root nodulation, efficient use of nutrients, $\mathrm{N}_{2}$ fixation and efficient partitioning of photosynthates from vegetative to reproductive parts (Gitari and Mureith, 2003). These results are in conformity with those that report a significant increase in $\mathrm{N}, \mathrm{P}$ and $\mathrm{K}$ content and uptake in the leaves or straw due to $\mathrm{P}$ application in soybean (Fatima et al., 2007).

Egypt. J. Soil Sci. 
TABLE 3. The effect of all treatments used on macronutrients uptake in seeds of soybean plants.

\begin{tabular}{|c|c|c|c|c|c|c|c|c|c|c|c|}
\hline \multirow{2}{*}{$\begin{array}{l}\text { Macronutrients } \\
\left.\text { (Kg fed }^{-1}\right)\end{array}$} & \multirow{2}{*}{$\begin{array}{c}P \\
\text { levels }\end{array}$} & \multicolumn{2}{|c|}{$\begin{array}{c}\text { Without Bio-P- } \\
\text { Fert. }\left(\mathrm{B}_{0}\right)\end{array}$} & \multicolumn{2}{|c|}{$\begin{array}{c}\text { With Bio-P- } \\
\text { Fert. }\left(\mathrm{B}_{1}\right)\end{array}$} & \multirow{2}{*}{$\begin{array}{c}\mathbf{P} \\
\text { Mean }\end{array}$} & \multicolumn{2}{|c|}{ Mean of P.F } & \multicolumn{2}{|c|}{ Mean of P.B } & \multirow{2}{*}{$\begin{array}{c}\text { L.S.D at } \\
5 \%\end{array}$} \\
\hline & & $F_{0}$ & $F_{1}$ & $F_{0}$ & $F_{1}$ & & $F_{0}$ & $F_{1}$ & $\mathrm{~B}_{0}$ & $\mathrm{~B}_{1}$ & \\
\hline \multirow{5}{*}{$\mathrm{N}$} & $P_{0}$ & 37.78 & 42.09 & 42.90 & 58.78 & $4539^{c}$ & $40.34^{c}$ & $50.44^{3 h}$ & $39.93^{b}$ & $50.84^{a}$ & \multirow{5}{*}{$\begin{array}{ll}\text { P } & 19.98 \\
\text { B } & 15.16 \\
\text { F } & 12.49 \\
\text { P.B } & 39.95 \\
\text { P.F } & 17.67 \\
\text { B.F } & \text { N.S } \\
\text { P.B.F } & \text { N.S }\end{array}$} \\
\hline & $\mathbf{P}_{1}$ & 42.91 & 46.71 & 53.07 & 69.71 & $53.10^{b}$ & $41.99^{\mathrm{bc}}$ & $58.21^{3 /}$ & $44.81^{2}$ & $6139^{2}$ & \\
\hline & $\mathbf{P}_{2}$ & 4850 & 50.21 & 66.49 & 83.02 & $6196^{2}$ & $57.49^{\text {she }}$ & $66.62^{2}$ & $4936^{2}$ & $74.76^{a}$ & \\
\hline & $\mathbf{P}_{3}$ & 5239 & 52.96 & 63.51 & 78.78 & $62.06^{\mathrm{a}}$ & $57.95^{3 b c}$ & $65.87^{2}$ & $52.67^{2}$ & $71.14^{\mathrm{a}}$ & \\
\hline & Mean & 45.40 & 48.0 & 56.50 & 7257 & 55.63 & 50.94 & 60.29 & 46.7 & 6453 & \\
\hline \multirow{5}{*}{$\mathbf{P}$} & $\mathbf{P}_{\mathbf{0}}$ & 2.17 & 2.78 & 296 & 3.48 & $2.85^{\mathrm{d}}$ & 2.57 & 3.13 & $2.48^{\mathrm{e}}$ & $3.22^{\mathrm{d}}$ & \multirow{5}{*}{$\begin{array}{ll}\text { P } & 0.25 \\
\text { B } & 0.11 \\
\text { F } & 0.18 \\
\text { P.B } & 0.50 \\
\text { P.F } & \text { N.S } \\
\text { B.F } \quad \text { N.S } \\
\text { P.B.F } \\
\text { N.S }\end{array}$} \\
\hline & $\mathbf{P}_{1}$ & 3.19 & 3.35 & 358 & 4.22 & $358^{t}$ & 3.38 & 3.78 & $3.27^{-1}$ & $390^{c}$ & \\
\hline & $\mathbf{P}_{2}$ & 3.41 & 3.90 & 5.44 & 631 & $4.61^{3}$ & 4.43 & 5.11 & $3.66^{6 d}$ & $5.88^{\mathrm{a}}$ & \\
\hline & $\mathbf{P}_{3}$ & 3.67 & 4.38 & 4.65 & 5.75 & $4.17^{h}$ & 4.16 & 5.07 & $4.03^{c}$ & $5.20^{\mathrm{b}}$ & \\
\hline & Mean & 3.11 & 3.60 & 4.16 & 494 & 3.80 & 3.64 & 4.27 & 336 & 455 & \\
\hline \multirow{5}{*}{$\mathbf{K}$} & $\mathbf{P}_{\mathbf{0}}$ & $9.78^{h}$ & $11.13^{g h}$ & $1156^{\mathrm{g}}$ & $14.29^{f}$ & $11.70^{c}$ & $10.64^{\mathrm{f}}$ & $12.71^{e}$ & $10.46^{f}$ & $12.94^{\mathrm{e}}$ & \multirow{5}{*}{$\begin{array}{ll}\text { P } & 0.63 \\
\text { B } & 0.63 \\
\text { F } & 0.56 \\
\text { P.B } 1.27 \\
\text { P.F } 0.79 \\
\text { B.F N.S. } \\
\text { P.B.F } \\
\text { l.57 }\end{array}$} \\
\hline & $P_{1}$ & $11 . A 2^{g}$ & $14.51^{\mathrm{ef}}$ & $15.44^{\mathrm{ef}}$ & $20.03^{c}$ & $15.35^{b}$ & $13.43^{\mathrm{d}}$ & $17.27^{b}$ & $12.97^{\mathrm{e}}$ & $17.73^{\mathrm{C}}$ & \\
\hline & $\mathbf{P}_{2}$ & $14.46^{f}$ & $14.78^{e t}$ & $17.20^{\mathrm{d}}$ & $24.41^{\mathrm{2}}$ & $17.46^{2}$ & $15.83^{C}$ & $1959^{2}$ & $14.62^{\mathrm{d}}$ & $20.80^{2}$ & \\
\hline & $\mathbf{P}_{3}$ & $15.01^{\mathrm{ef}}$ & $16.05^{d e}$ & $16.05^{d e}$ & $22.62^{b}$ & $17.71^{a}$ & $1558^{\mathrm{C}}$ & $1933^{2}$ & $1553^{\mathrm{d}}$ & $1938^{b}$ & \\
\hline & Mean & 12.67 & 14.12 & 15.06 & 20.34 & 1556 & 13.87 & 17.23 & 13.40 & 17.71 & \\
\hline
\end{tabular}

$F_{0}=$ without foliar application $F_{1}=$ with foliar app lication $P_{0}=$ without $P$ fertilizer $P_{1}=15 \mathrm{~kg} P_{2} O_{5} / f_{e d} \quad P_{2}=225 \mathrm{~kg} P_{2} O_{5} / f e d \quad P_{3}=30 \mathrm{~kg} P_{2} O_{5} / f$ fed 
Concerning the effect of foliar application of micronutrients under different levels of $\mathrm{P}$ fertilizer, the data in Table 3 showed that $\mathrm{N}$ and $\mathrm{K}$ uptake were significantly affected. Also, the data reveal that $\mathrm{P}_{3}$ with foliar applied achieved the highest values of macronutrient uptake. This may be due to the effect of micronutrients which can play an important role in the availability of phosphorus in the soil. Imtiaz et al. (2003) stated that adequate nutrition of plant with micronutrients depends on many factors. Among them is the ability of soil to supply these nutrients, rate of nutrients absorption by the plants, distribution of nutrients to function sites and nutrients mobility within the plant. In this respect, El-Fouly and Fawzi (1996) noticed that micronutrients application encourages the growth of roots, which in turn take up higher contents of $\mathrm{N}, \mathrm{P}$ and $\mathrm{K}$ and finally being reflected on the yield.

Regarding the effect of interaction between $\mathrm{P}$ biofertilizer and different levels of mineral phosphorus fertilizer, the results in Table 3 show that there was a significant enhancement in the uptake of $\mathrm{N}, \mathrm{P}$ and $\mathrm{K}$ in comparison to plants untreated with biofertilizer. It is also reported that, $\mathrm{P}_{2}+\mathrm{P}$ biofertilizer gave the highest values compared with the other levels of phosphorus fertilizer. This may be explained as the application of biofertilizers could make such nutrients more available for plants. While, the combined treatment of P-biofertilizer and foliar spray of micronutrients insignificantly increases the uptake of $\mathrm{N}, \mathrm{P}$ and $\mathrm{K}$. Phosphate solubilizing microorganisms increased available phosphorus and nitrogen in the soil which increases their concentration by plant, also increased the grain protein. Likewise, phosphate solubilizing bacteria have the capability to solubilize the residual or fixed soil $\mathrm{P}$ and increase the availability of $\mathrm{P}$ in the soil (Singh et al., 2008) producing the growth promoting substances (Selvakumar et al., 2012) and thereby increase the overall P-use efficiency of the crops. Moreover, bio-phosphate bacteria efficiency increased by application of biological phosphorus fertilizer combined with chemical phosphorus fertilizer. Mahfouze and Sharaf - Eldin (2007) reported that phosphorus solvent bacteria have the ability to produce organic acids that would increase solubility of phosphorus available for plant. It can be noted that plants treated with $\mathrm{P}$ biofertilizer and foliar application of micronutrients were more effective than plants without them, they were recording $38 \%, 35 \%$ and $32 \%$ for $\mathrm{N}, \mathrm{P}$ and $\mathrm{K}$ uptake, respectively.

Regarding the trible interaction, the data in Table 3 illustrated that $\mathrm{N}$ and $\mathrm{P}$ uptake showed non-significant response to applied mineral $\mathrm{P}+\mathrm{P}$ bio + foliar micronutrients, while $\mathrm{K}$ uptake significantly responsed. The data showed that maximum values of $\mathrm{N}, \mathrm{P}, \mathrm{K}$ uptake under $\mathrm{P}_{2}+\mathrm{B}_{1}+$ foliar were obtained than those in treatments which received other levels of phosphorus mixed with biofertilizer and foliar application or that achieved by the single use of inorganic $\mathrm{P}$ fertilizer or either of $\mathrm{P}$ bio-fertilizer and foliar micronutrient. In general, application of $\mathrm{P}_{2}+\mathrm{B}_{1}+$ foliar exhibited the best treatments in enhancing the uptake of the studied macronutrients by seeds as it achieved $58 \%, 71 \%$ and $63 \%$ increases in $\mathrm{N}, \mathrm{P}$ and $\mathrm{K}$ uptake by seeds, respectively comparing with $\mathrm{P}_{3}(30 \mathrm{~kg}$ $\mathrm{P}_{2} \mathrm{O}_{5}$ ) without bio-fertilizer or micronutrients spraying. It is interesting to mention Egypt. J. Soil Sci. 
that the high increased uptake could be explained as a result of the remarkable increase in the seeds weight of yield achieved by this treatment. This increase is mainly attributed to the effect of microorganisms which can play a very significant role in making available nutrients elements for plants. It is essential to bring about some microbial transformation of both inorganic and organic compounds in the soil to make available of these elements to soybean plant. These results are in agreement with those found by Cabrera (2006) who reported that the application of biofertilizers enabled plants to extract a higher amounts of $\mathrm{N}, \mathrm{P}, \mathrm{K}, \mathrm{Ca}^{+2}$ and $\mathrm{Mg}^{+2}$ and increased yield.

\section{Micronutrients}

Data in Table 4 show that the positive effect of $\mathrm{P}$ application on $\mathrm{Fe}, \mathrm{Zn}$ and $\mathrm{Mn}$ uptake and graded the rate of $\mathrm{P}$ application up to $\mathrm{P}_{3}$ achieved the highest values over that of $\mathrm{P}_{0}$. Application of bio-fertilizer or micronutrients spraying individually caused significant superiority in the uptake of micronutrients to that without any of them. This may be due to improved physical and chemical properties of the soil and increased the available nutrients to plant. Foliar application is very fast method for providing required elements in plant because nutrients are taken up quickly as compared to that through plant roots (ElHaggan, 2014).

The double interaction between each of those three factors and another presented in Table 4 clarifies that the combination of bio-fertilizer with $\mathrm{P}$ at the rate $\mathrm{P}_{2}$ was the best and significantly encouraged the uptake of micronutrients (El-Gizawy and Mehasen, 2009). While the effect of combined treatment between $\mathrm{P}$ application and foliar spraying with micronutrients had insignificant effect on the uptake of Mn only. Also, the interaction between P-biofertilizer and foliar micronutrients caused significant increase in the uptake of $\mathrm{Fe}$ and $\mathrm{Mn}$. The increase percent for plants treated with $\mathrm{P}$ biofertilizer and foliar application of micronutrients were more effective than plants without $\mathrm{P}$ biofertilizer and foliar application of micronutrients recording 22\%, $42 \%$ and $104 \%$ for $\mathrm{Fe}, \mathrm{Zn}$ and $\mathrm{Mn}$ uptake, respectively.

Regarding the effect of the three factors together on uptake of micronutrients, the results reveal that $\mathrm{Fe}$ and $\mathrm{Mn}$ significantly responded while, $\mathrm{Zn}$ was insignificant. As well as the results mentioned that $\mathrm{P}_{3}+\mathrm{P}$ - biofertilizer + foliar spraying of micronutrients gave the highest values compared to the other levels of $\mathrm{P}$ application due to promoting root growth which in turn enhancing nutrients and water uptake from the soil. The relative increase was 28,82 and $195 \%$ (for $\mathrm{Fe}, \mathrm{Zn}$ and $\mathrm{Mn}$, respectively) comparing with $\mathrm{P}_{3}\left(30 \mathrm{~kg}_{2} \mathrm{O}_{5}\right)$ without bio-fertilizer or micronutrients spraying (Zaghloul et al., 2015). In this regard, zinc absorption reduced by phosphorus application in the soil, but biological phosphorus fertilizers due to having phosphate solubilizing bacteria had no interference on other elements uptake (Solimpour et al., 2010). 
TABLE 4. The effect of all treatm ents used on micronutrients uptake in seeds of soybean plants.

\begin{tabular}{|c|c|c|c|c|c|c|c|c|c|c|c|}
\hline \multirow{2}{*}{$\begin{array}{l}\text { Micronutrients } \\
\text { (gm/fed) }\end{array}$} & \multirow[t]{2}{*}{$\begin{array}{c}\mathrm{P} \\
\text { levels }\end{array}$} & \multicolumn{2}{|c|}{$\begin{array}{c}\text { Without Bio-P- } \\
\text { Fert. }\left(\mathrm{B}_{0}\right)\end{array}$} & \multicolumn{2}{|c|}{$\begin{array}{c}\text { With Bo-P- } \\
\text { Fert.(B) }\end{array}$} & \multirow{2}{*}{$\begin{array}{c}P \\
\text { mean }\end{array}$} & \multicolumn{2}{|c|}{ Mean of P.F } & \multicolumn{2}{|c|}{ Mean of P.B } & \multirow{2}{*}{$\begin{array}{c}\text { L.S.D at } \\
5 \%\end{array}$} \\
\hline & & $F_{0}$ & $F_{1}$ & $F_{0}$ & $F_{1}$ & & $F_{0}$ & $F_{1}$ & $\mathrm{~B}_{0}$ & $\mathrm{~B}_{1}$ & \\
\hline \multirow{5}{*}{$\mathbf{F e}$} & $P_{0}$ & $114.59^{\mathrm{m}}$ & $114.91^{\mathrm{m}}$ & $119.69^{\mathrm{m} n}$ & $135.92^{\mathrm{jk}}$ & $121.28^{x}$ & 117.14 & 125.41 & $114.75^{\mathrm{h}}$ & $127.81^{\mathrm{g}}$ & \multirow{5}{*}{$\begin{array}{l}\text { P } 4.22 \\
\text { B } 4.79 \\
\text { F } 2.86 \\
\text { P.B } 9.58 \\
\text { P.F N.S } \\
\text { B.F } 4.05 \\
\text { P.B.F } \\
8.09\end{array}$} \\
\hline & $P_{1}$ & $128.20^{\mathrm{k}}$ & $138.03^{\overline{7}}$ & $15857^{6}$ & $184.30^{c}$ & $152.28^{b}$ & 14339 & 161.17 & $133.12^{\mathrm{f}}$ & $171.44^{c}$ & \\
\hline & $P_{2}$ & $149.66^{h}$ & $150.25^{\mathrm{gh}}$ & $182.06^{\circ}$ & $218.52^{a}$ & $173.12^{a}$ & 16586 & 184.39 & $149.96^{e}$ & $200.29^{a}$ & \\
\hline & $P_{3}$ & $158.27^{\mathrm{fg}}$ & $166.09^{d}$ & $173.88^{\text {de }}$ & $10495^{b}$ & $175.30^{\mathrm{a}}$ & 166.08 & 180.52 & $162.18^{1}$ & $184.42^{b}$ & \\
\hline & Mean & 137.68 & 142.32 & 158.55 & 183.42 & 15550 & 148.12 & 162.87 & 1400 & 1710 & \\
\hline \multirow{5}{*}{$\mathrm{Z}$ n } & $P_{0}$ & 35.2 & 40.12 & 43.12 & 52.65 & 42. $78^{x}$ & 39.17 & 46.39 & $37.67^{e}$ & $47.88^{x d}$ & \multirow{5}{*}{$\begin{array}{ll}\text { P } & 3.66 \\
\text { B } & 2.74 \\
\text { F } & 2.21 \\
\text { P.B } & 5.48 \\
\text { P.F } & \text { N.S } \\
\text { B.F N.S } & \text { N.S } \\
\text { P.B.F } \\
\text { N.S }\end{array}$} \\
\hline & $P_{1}$ & 40.74 & 4451 & 5359 & 72.72 & $52.89^{b}$ & 47.17 & 58.62 & $42.62^{\mathrm{de}}$ & $63.16^{b}$ & \\
\hline & $P_{2}$ & 44.33 & 48.15 & 64.47 & 86.63 & $59.70^{2}$ & 54.35 & 67.39 & $46.19^{1}$ & $75.55^{\mathrm{a}}$ & \\
\hline & $P_{3}$ & 47.50 & 57.65 & 5690 & 76.75 & $60.87^{2}$ & 52.20 & 67.20 & $52.58^{\prime}$ & $66.83^{b}$ & \\
\hline & Mean & 41.94 & 47.61 & 5452 & 72.19 & 54.06 & 48.22 & 59.90 & 44.77 & 63.36 & \\
\hline \multirow{5}{*}{ Mn } & $P_{0}$ & $8.10^{\circ}$ & $129 g^{\gamma i}$ & $1430^{g h t}$ & $28.27^{1}$ & $15.92^{c}$ & $11.20^{e}$ & $20.63^{\mathrm{xd}}$ & $10.55^{\mathrm{g}}$ & $21.29^{\mathrm{d}}$ & \multirow{5}{*}{$\begin{array}{ll}\text { P } & 2.69 \\
\text { B } & 1.65 \\
\text { F } & 1.10 \\
\text { P.B } & 3.29 \\
\text { P.F } & 3.12 \\
\text { B.F } 0.55 \\
\text { P.B.F } \\
\text { 3.11 }\end{array}$} \\
\hline & $P_{1}$ & $11.00^{\overline{\mathbf{p}}}$ & $16.48^{\mathrm{g}}$ & $25.01^{e}$ & $31.80^{\circ}$ & $21.07^{b}$ & $18.00^{d}$ & $24.14^{b}$ & $13.74^{4}$ & $28.40^{\circ}$ & \\
\hline & $\mathrm{P}_{2}$ & $13.83^{\text {gii }}$ & $1931^{\mathrm{fg}}$ & $30.63^{\mathrm{cd}}$ & $44.91^{\mathrm{a}}$ & $26.16^{2}$ & $22.23^{b c}$ & $32.11^{\mathrm{a}}$ & $1657^{\mathrm{t}}$ & $37.7^{a}$ & \\
\hline & $P_{3}$ & $15.22^{\text {gh }}$ & $21.82^{f}$ & $28.71^{\mathrm{cd}}$ & $38.89^{b}$ & $27.17^{a}$ & $21.97^{\text {he }}$ & $30.35^{2}$ & $18.58^{e}$ & $33.80^{b}$ & \\
\hline & Mean & 12.04 & 17.65 & 24.66 & 3597 & 22.58 & 18.35 & 24.31 & 14.86 & 30.30 & \\
\hline
\end{tabular}

$F_{0}=$ without foliar app lication $F_{1}=w$ ith foliar application $P_{0}=$ without $P$ fertilizer $P_{1}=15 \mathrm{~kg} P_{2} O_{5} / f$ fed $P_{2}=225 \mathrm{~kg} P_{2} O_{5} /$ fed $P_{3}=30 \mathrm{~kg} P_{2} O_{5} / f e d$ 


\section{Yields of protein and oil}

Data presented in Table 5 reveal that raising the rate of $\mathrm{P}$ application up to $\mathrm{P}_{3}$ significantly increased the contents of protein and oil in comparison with untreated plant. In addition, application of bio-fertilizer or spraying micronutrients individually caused significant response in the content of protein and oil over to that without any of them (El-Haggan, 2014) Concerning the combined effect between different levels of $\mathrm{P}$ application and both of $\mathrm{P}$ solubilizing bacteria and foliar spraying of micronutrients, the results in Table 5 reveal that protein and oil contents were significantly affected by using foliar treatment and $\mathrm{P}_{3}$ recorded the highest values. Amara (1998) found also that spraying with micronutrients resulted in a large increase in protein content of broad bean. Hemati (2005) reported that wheat protein increased by application of micronutrients such as $\mathrm{Zn}, \mathrm{Mn}$ and $\mathrm{Fe}$. In addition, the results mentioned that $\mathrm{P}_{2}+\mathrm{P}$ biofertilizer gave the highest values of protein and oil contents compared with the other levels of phosphorus fertilizer. In this connection Saber et al. (1989) reported that application of bio-fertilizer increased oil and protein contents as well as nutrient elements in soybean seeds. It can be noted that plants treated with $\mathrm{P}$ biofertilizer and foliar application of micronutrients were more effective than plants without $\mathrm{P}$ biofertilizer and foliar application of micronutrients recording 36 and $28 \%$ for protein and oil contents, respectively.

Furthermore, the effect of three factors on content of protein and oil was insignificant, but, the treatment of $\mathrm{P}_{2} \mathrm{~B}_{1} \mathrm{~F}_{1}$ was the best one and achieved relative increase 58 and $43 \%$ for protein and oil contents compared with $\mathrm{P}_{3}$ (30 kg $\mathrm{P}_{2} \mathrm{O}_{5}$ ) without bio-fertilizer or micronutrients spraying.The increased protein mainly due to the increase in $\mathrm{N}$ content means that biofertilizers can provide plants with essential nutrients elements required for oil and protein formation. These results are in line with those obtained by El-Kholy and Gomaa (2000). The application of inorganic P fertilizer and PBF with foliar micronutrient might have assured $P$ availability and its subsequent utilization for formation of carbon skeletons and for the synthesis of amino acids and ATP that, in turn, might have led to an enhanced synthesis of protein during soybean seed development (Trwari and Pal, 2005). However, $\mathrm{P}_{2}+\mathrm{PBF}+$ foliar application of micronutrients was found to be the best interaction between inorganic $\mathrm{P}$ levels and bio-fertilizers treatment with micronutrients. In general, microorganism can play a very significant role in making available phosphorus to plants. It is essential to bring about some microbial transformations of both inorganic and organic compounds in soil to make available of this element to plant. 


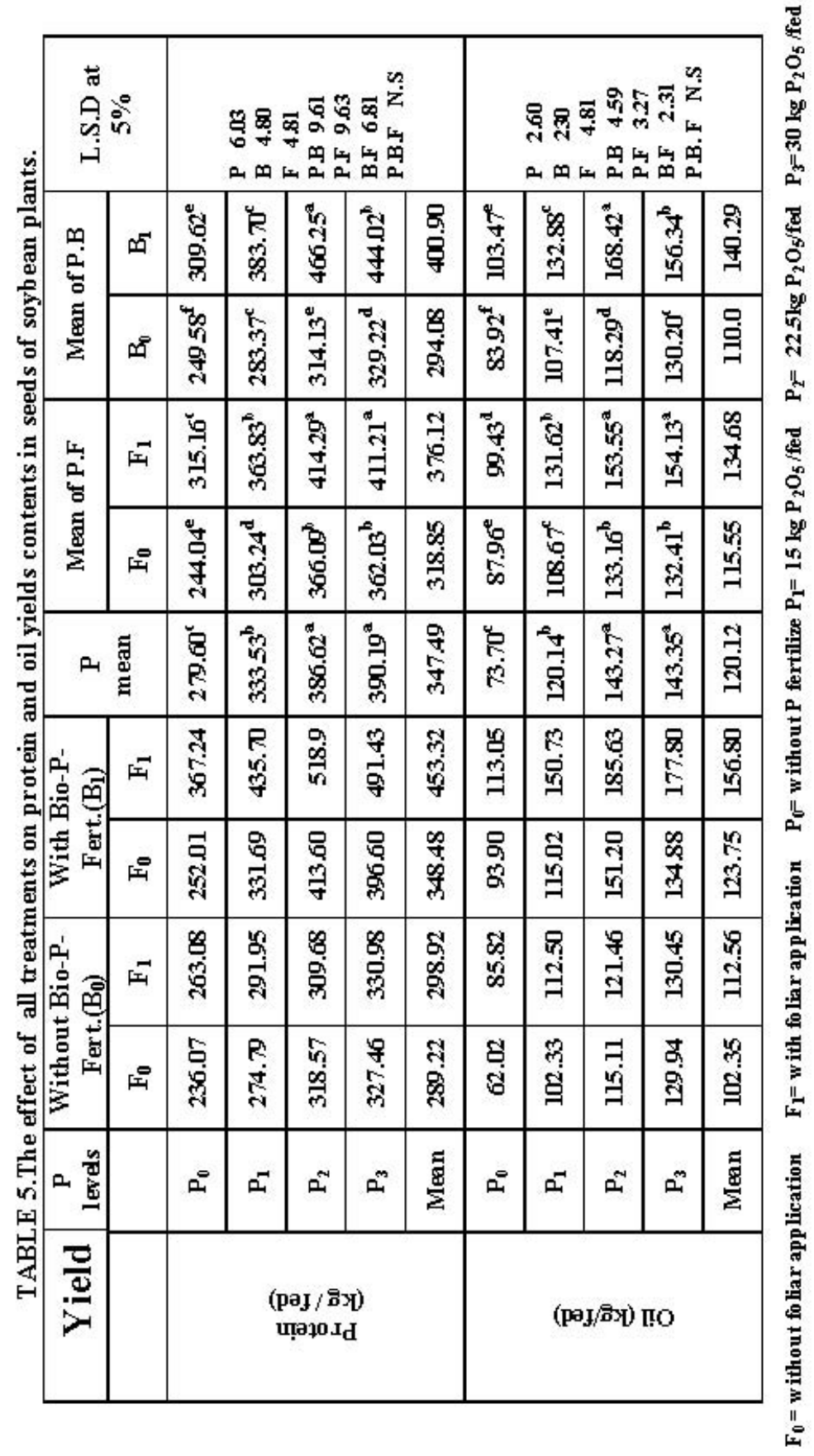

Egypt. J. Soil Sci. 


\section{Conclusion}

In the light of the obtained results, it could be concluded that a combined application of $22.5 \mathrm{~kg} \mathrm{P} \mathrm{O}_{5} / \mathrm{fad}\left(\mathrm{P}_{2}\right)+\mathrm{P}$ biofertilizer+ foliar micronutrients was generally significant and provided the best condition for achieving maximum yield and its quality attributes. In general, environmental pollution could be reduced by decreasing consumption of chemical fertilizer. Overall, application of $\mathrm{P}$ biofertilizer with mineral phosphorus fertilizer and foliar micronutrients in addition to yield increasing could be a strategy to achieve sustainable agriculture. Therefore, the integrated fertilization including mineral (macro- and micronutrients) and bio-fertilizers can be considered an important strategy for sustainable agriculture.

\section{References}

Abdelhamid, M.T. and I. M. El-Metwally (2008) Growth, nodulation and yield of soybean and associated weeds as affected by weed management. Planta Daninha. 26 (4), $855-863$.

AOAC (1990) Official Methods of Analysis Official Analysis Agricular Chemists, $15^{\text {th }}$ ed. Washington, D.C.U.S.A.

Agwu, A. E., Ellah, J., Ekweagwu, E. and Iwuchukwu, J. C. (2009) Consumption patterns and intrahousehold roles in the production, processing and marketing of soybeans in the Northern agricultural zone of Benue State, Nigeria. African Journal of Biotechnology, 8(4), 605-613.

Ahmed, M.A. and EL-Abagy, H.M.H. ( 2007) Effect of bio-and mineral phosphorus fertilizer on the growth, productivity and nutritional value of some faba bean (Vicia faba L.) cultivars in newly cultivated land. J. of Appl. Sci. Res., 3(6), 408-420.

Ali, S, Riaz, A. K. Ghazal, M. Arif, M. and Fida, B. (2008) Assessment of different crop nutrient management practices for yield improvement. Applied Sciences Journal of Crop Science, 2(3),150-157.

Amara, M. A. T. (1998) Soybean response to inoculation with biofertilizer and fertilization with micro-nutrients in calcareous soil. Desert-Institute-Bulletin. Egypt. 48(1), 75-92.

Cabrera, A. R. (2006) Horticultural crop bio-fertilization with Arbuscular mycorrhizal fungi. Soil Science of World Congress, July 9-15. Philadelphia, Pennsylvania, USA.

Carsky, R. J., Singh, B.B. and R. Oyewole (2001) Contribution of early - season cowpea to late season maize in the savanna zone of West Africa. Biol. Agric. Hort., 18, 303-315.

Dutta, D. and Prohit, B. (2009) Performance of chickpea (Cicer arietinum L.) to application of phosphorus and biofertilizer in laterite soil. Arch. Agron. Sci. 55, 147-155.

El-Fouly, M. and Fawzi, A. A. (1996) Fertilizer Use in the Near East Agriculture : Over View. Regional Workshop on Fertilizer Use for Sustainable Agriculture. Amman . Jorden. 4-6. 
El-Gizawy, N. K. B. and Mehasen, S. A. S. (2009) Response of faba bean to bio, mineral phosphorus fertilizers and foliar application with zinc. World Applied Sciences Journal, 6(10), 1359-1365.

El-Haggan, E.A.M. (2014) Effect of micronutrients foliar application on yield and quality traits of soybean cultivars. Int. J. of Agric. and Crop. Sci. 7 (11), 908- 914.

El-Kholy, M.A. and Gomaa, A.M. (2000) Biofertilizers and their impact on forage yield and N-content of millit under low level of mineral fertilizers. Annals of Agric. Sci. Moshtohor, Egypt, 38(2), 813-822.

Fatima Z., Zia, M. and Chaudhary, M. F. (2007) Interactive effect of Rhizobium strains and $\mathrm{P}$ on soybean yield, nitrogen fixation and soil fertility. Pak. J. Bot. 39, 255264.

Gitari, J. N. and Mureith, J. G. (2003) Effect of phosphorus fertilization on legume nodule formation and biomass production in Mount Kenya Region. East. Afr. Agri. J. 9,183-187.

Hamed, M. F. (2003) Faba Bean productivity as affected by zinc, phosphorus fertilizer and phosphorin. Annal of Agric. Sci., Moshtohor, 41 (3),1109-1119.

Hemati, A. (2005) Application of soil and spray application of iron, zinc and manganese on yield and bean protein plant. (The first National Conference Beans Proceedings) Institute for Plant Science Ferdowsi University of Mashhad, Iran 2: 387-390.

Hymowitz, T. F., Collins, P. and Walker, W.M. (1972) Relationship between the content of oil, protein and sugar in soybean seed. Agron. J. 64, 613-616.

IIbas, A. I. and Sahn, S. (2005) Glomus fasciculatum inoculation improves soybean production. Acta-Agriculturae-Scandinavia-Section-B,soil $\mathrm{n}$ plant science . India, 55(4), 287-292.Inc. Publisher Madison ,Wisconsin ,USA

Imtiaz, B. J., Alloway, K. H., Sahn, S. H., Siddiqui, M. Y., Memon, M. A. and Khan, P. (2003) Zinc nutrition of wheat : Interacion of zinc with other trace elements. Asian Journal of Plant Science. 2(2), 156-160.

Kakar, K.M., Tariq, M., Taj, F.H. and Nawab, K. (2002) Phosphorous use efficiency of soybean as affected by phosphorous application and inoculation. Pak. J. Agron. 1(1), 49-50.

Kannayan, S. (2002) Biofertlizers for Sustainable Crop Production, Biothecnology of Biofertilizers. Narosa Publishing House, New Delhi, India, 9-49.

Kashturikrishna, S. and Ahlawat, P. S. (1999) Growth and yield response of pea (Pissum sativum) to moisture stress, phosphorus, sulphur and zink fertilizers. Indian J. Agron., 44, 588-596.

Klute, A. (1986) "Methods of Analysis". Part 1, Soil Physical Properties. ASA and SSSA, Madison, WI. J of American Society of Agronomy. 9 (1), pp. 1188. 
Mahfouz, S. A. and Sharaf-Eldin, M. A. (2007) Effect of mineral biofertilizer on growth, yield and essential oil content of fennel. International Agro-physics, 21, 361-366.

Mekail, M.M., Maatouk, M.A., Zanouny, I. Fouaad, M. and Abd El-Aziz, S.M. (2005) Response of corn and faba bean to bio-fertilization. Minia J. of Agric.Res. \& Develop, 25(3), 421-436.

Mevi Schütz, T., Goverde, J.M. and Erhardt, A. (2003) Effects of fertilization and elevated $\mathrm{CO}_{2}$ on larval food and butterfly nectar amino acid preference in Coenonym phapamphilus L. Behavioral Ecology and Sociobiology, 54, 36-43.

Page, A. L. R., Miller, H. and Keeney, D. R. (1982) Methods of Soil Analysis. Part 2: Chemical and Microbiological Properties. $2^{\text {nd }}$ ed, Agronomy Monograph, No. 9, ASA, CSSA, and SSSA, Madison.

Qasim S. M., Farrukh Saleem, M. , Khan, H. Z. and Anjum, S. A. (2009) Performance of soybean (Glycin max L.) under different phosphorus levels and inoculation. Pak. J. Agri. Sci. 46(4), 1-5.

Saber, M. S. M., El-Baz, F. K. and Kabesh, M. O. ( 1989) Utilization of biofertilizers in increasing field crop production. 6. Effect of elemental sulphur application and / or biofertilization on the chemical composition of soybean seeds. Egyptian J. Agron. 14(1), 241-252.

Solimpour, S., Khavazi, K., Nadian, H. Besharati, H. and Miransari, M. (2010) Enhancing phosphorus availability to canola (Brassica napus L.) using p solubilizing and sulfur oxidizing bacteria. Australian Journal of Crop Science, 4(5), 330-333.

Selvakumar, G., Reetha, S. and Thamizhiniyan, P. (2012) Response of biofertilizers on growth, yield attributes and associated protein profiling changes of blackgram (Vigna mungo L. Hepper). World App. Sci. J. 16, 1368-1374.

Singh, R.P., Gupta, S.C. and Yadav, A.S. (2008) Effect of levels and sources of phosphorus and PSB on growth and yield of blackgram (Vigna mungo L. Hepper). Legume Res. 31, 139-141.

Snedecor, G. W. and Cochran, W. G. (1990) Statistical Methods, $8^{\text {th }}$ ed. Iowa State Univ., Press, Ames, Iowa, USA

Tomar, S. S., Singh, R. and Singh, P.S. (2004) Response of phosphorus, sulphur and Rhizobium inoculation on growth, yield and quality of soybean. Prog. Agric. 4(1), 72-73.

Trwari, S. and Pal, R. S. (2005) Effect of phosphorus and potassium on yield ,quality, economic and balance studies of soybean. Res. Crops, 6, 446-447.

Turan, M., Afaoglu, N. and Sahin, F. (2006) Evaluation of the capacity of phosphorus solubilizing bacteria and fungi on different form of phosphorus in liquid culture. $J$. Sustain Agri. 28, 99-108.

Uddin M., Hussain, S., Masroor, M., Khan, A., Hashmi, N., Idrees, M., Naeem, M. and Ahmed Dar, T. (2014) Use of $\mathrm{N}$ and $\mathrm{P}$ biofertilizers reduces inorganic 
phosphorus application and increases nutrient uptake, yield and seed quality of chickpea. Turkish Journal of Agriculture and Forestry, 38, 47-94.

Yaklich, R.W., Vinyard, B., Camp, M. and Douglass, S. (2002) Analysis of seed protein and oil from soybean northern and southern region uniform tests. Crop Sci., 42, 1504-1515

Zayed, B. A., Salem, A.K.M. and El-Sharkawy, H.M. (2011) Effect of different micronutrient treatments on rice (Oriza sativa $\mathrm{L}$.) growth and yield under saline soil conditions. World J. of Agric. Sci. 7 (2), 179-184.

Yilmaz, S. (2008) Effects of increased phosphorus rates and plant densities on yield and yield-related traits of narbon vetch lines. Turk. J. Agric., 32, 49-56.

Zaghloul, R.A., Abou-Aly, H.E., El-Meihy, R.M. and Mohamed, T. E. (2015) Improvement of growth and yield of pea plants using intergrated fertilization management. Univ. J. of Agric. Res. 3 (4), 135- 143.

Zarei, I., Yousef, S., Gholam, R.H.. Ali, J. and Mohammadi, K. (2012) Effect of biofertilizer on grain yield and protein content of two soybean (Glycin max L.) cultivars. African J. of Biotech.11 (27), 028-7037.

(Received17/4/2016, acecpted12/7/2016) 


\section{تقييم استخدام التسميد الحيوى والمعدنى للفوسفور مع الرش في التودي

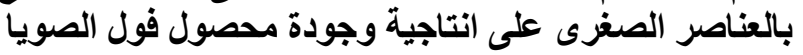

منال عبد الحكم عطية ، داليا عدروز سيد و لمياء عبد الحليم عبد الرمن

$$
\text { معهد بحوث الاراضى والمياه والبيئة- مركز البحوث الزراعية - الجيزة سمصر }
$$

\footnotetext{
اقيمت تجربتان حقليتان خلال الموسم الصيفى 2013 و2014 في محطة بحوث

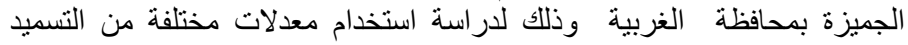

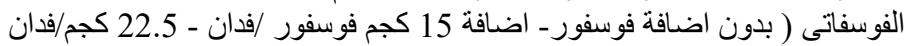

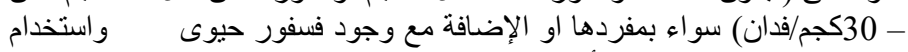
الرش بالعناصر الصغرى وتأثثر ذلك على محصول فول الألى الصويا ومكون فياته وجودنه. وقد كانت النتائج المتحصل عليها كما يلى :

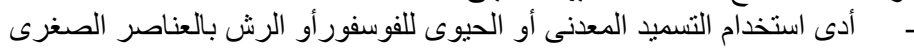

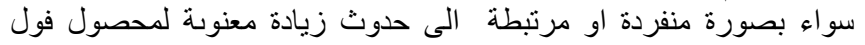

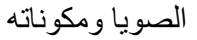
كذلك أظهرت النتائج ان أفضل معاملة كانت بأستخدام التسميد الفوسفاتى بمعدل

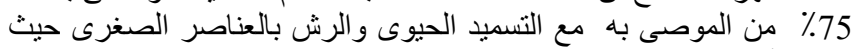

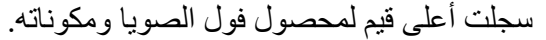

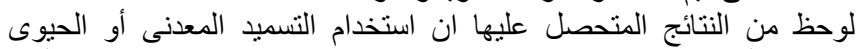

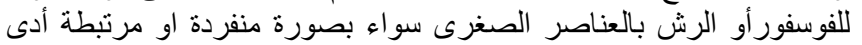

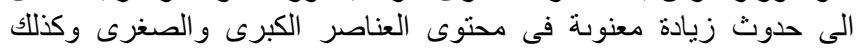
محتوى فول الصويا من البروتين و الزيت فئي

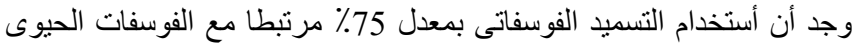

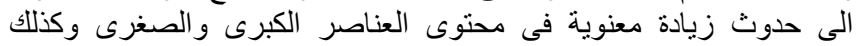

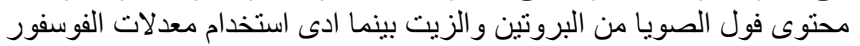

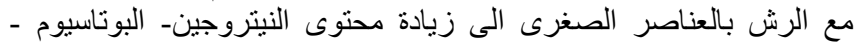

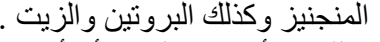

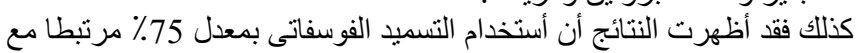

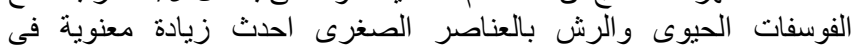

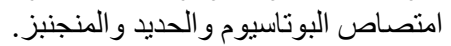

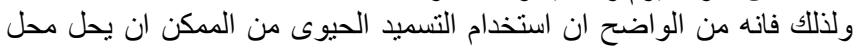

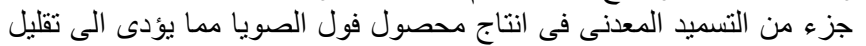
التلوث البيئى الناجم عن استخدام الاسمدة المعدنية.
} 